\title{
Pengembangan Sistem Informasi Pendaftaran Online Sekolah Putri Darul Istiqamah (SPIDI) Maros
}

\author{
Suhartina Najamuddin ${ }^{1}$, Mustari Lamada ${ }^{2}$, Syamsurijal $^{3}$ \\ Pendidikan Teknik Informatika dan Komputer, Universitas Negeri Makassar \\ ${ }^{1}$ tinasuhartinanajamuddin@gmail.com \\ ${ }^{2}$ mustarilamada@gmail.com \\ ${ }^{3}$ rijalkalang@gmail.com
}

\begin{abstract}
Abstrak- Penelitian ini bertujuan untuk mengetahui hasil pengembangan sistem informasi pendaftaran online dan tanggapan pengguna terhadap sistem informasi pendaftaran online pada Sekolah Putri Darul Istiqamah. Penelitian ini adalah penelitian dan pengembangan atau yang lebih dikenal dengan istilah Research and Development (R\&D) dan menggunakan incremental model sebagai model pengembangan. Tahapan pengembangan yaitu tahap communication, planning, modeling, construction, dan deployment. Data dikumpulkan menggunakan teknik wawancara, kuesioner, dan dokumentasi. Sistem divalidasi oleh dua orang ahli sistem, dua ahli media, dan dua ahli konten. Sistem juga dievaluasi oleh 32 orang responden. Hasil penelitian ini adalah sebuah sistem informasi yang dapat digunakan sebagai media pendaftaran online yang berbasis web di Sekolah Putri Darul Istiqamah. Sistem ini telah melewati pengujian menggunakan ISO 25010 pada aspek functional suitability, performance efficiency, compatibility, reliability, portability, dan aspek usability dengan hasil pengujian sukses tanpa error. Berdasarkan hasil pengujian tersebut maka dapat disimpulkan bahwa sistem informasi pendaftaran online Sekolah Putri Darul Istiqamah yang dikembangkan dinyatakan valid dan layak digunakan.
\end{abstract}

Kata kunci : Sistem Informasi, Pendaftaran Online, Sekolah Putri Darul Istiqamah

\section{PENDAhUluan}

Teknologi informasi adalah ilmu yang mempelajari tentang desain, pengembangan, implementasi, manajemen sistem informasi yang berbasiskan komputer, khususnya aplikasi software dan hardware (Yaumi, 2018). Lebih jauh teknologi informasi adalah suatu teknologi yang difungsikan untuk mengolah data, termasuk memproses, mendapatkan, menyusun, menyimpan, memanipulasi data dengan berbagai cara untuk menghasilkan informasi yang berkualitas (Yusa, 2016).

Perkembangan teknologi informasi dapat meningkatkan kinerja dan memungkinkan berbagai kegiatan dapat dilaksanakan dengan cepat, tepat dan akurat sehingga dapat meningkatkan produktivitas kerja. Perkembangan teknologi informasi telah memunculkan berbagai jenis kegiatan yang berbasis pada teknologi, seperti e-government, e-commerce, e-education, e-medicine, elaboratory, dan lainnya.

Perkembangan teknologi informasi yang tergolong cukup pesat sejalan dengan meningkatnya kebutuhan masyarakat. Selain perkembangan jenis peralatan teknologi maupun software aplikasi pendukung, perkembangan ini juga berdasarkan pada semakin meningkatnya pengguna teknologi informasi. Perkembangan teknologi informasi ini diperkuat dengan data yang dilaporkan oleh Badan Pusat Statistik pada Indeks Pembangunan Teknologi Informasi dan Komunikasi (IP-TIK).

Indeks Pembangunan Teknologi Informasi dan Komunikasi (IP-TIK) adalah suatu ukuran standar yang dapat menggambarkan tingkat pembangunan Teknologi Informasi dan Komunikasi (TIK) pada suatu wilayah. IP-TIK digunakan untuk mengukur pertumbuhan TIK baik di negara maju maupun negara berkembang, mengukur gap digital atau perbedaan antar negara dengan berbagai tingkat pembangunan TIK, mengukur tingkat pembangunan TIK di suatu negara menggunakan suatu ukuran yang dapat dibandingkan antarwaktu dan antarwilayah, serta mengukur potensi pembangunan TIK atau pengembangannya untuk mendorong pertumbuhan pembangunan berdasarkan kemampuan dan keahlian yang tersedia.

Berdasarkan data yang diberikan oleh Badan Pusat Statistik maka dapat disimpulkan bahwa IP-TIK Indonesia dari tahun ke tahun mengalami peningkatan, baik dari akses dan infrastruktur, penggunaan, dan keahlian. Hal ini dapat dilihat bahwa pada tahun 2015, IP-TIK Indonesia adalah 3,88. Kemudian pada tahun 2016, IP-TIK Indonesia mencapai 4,34. Kemudian di tahun 2017, IP-TIK Indonesia mencapai angka 4,99. Untuk IP-TIK tingkat Provinsi, pada tahun 2016 provinsi Sulawesi Selatan menduduki peringkat ke-13 dengan angka mencapai 4,26 dengan kategori IP-TIK tergolong sedang, dan pada tahun berikutnya, yakni tahun 2017, IPTIK untuk provinsi Sulawesi Selatan meningkat dengan menduduki peringkat ke-12 dan nilai mencapai 4,86. Meski angka dan peringkat IP-TIK provinsi Sulawesi Selatan mengalami peningkatan yang cukup baik namun IP-TIK provinsi Sulawesi Selatan masih tergolong sedang (BPS, 2018).

Hal ini juga diperkuat dengan informasi yang disampaikan oleh Kementerian Komunikasi dan Informatika (Kemkominfo) yang menyatakan bahwa pengguna internet di Indonesia hingga saat ini telah mencapai 82 juta orang. Dengan capaian tersebut, Indonesia berada pada peringkat ke-8 di dunia (Kominfo, 2014). Capaian tersebut terjadi pada tahun 2014. Adanya perkembangan teknologi dan pemerataan pengguna teknologi maka dapat dipastikan bahwa pada tahun 2019 angka pengguna internet juga mengalami peningkatan.

Perkembangan teknologi yang sangat cepat membuat semuanya harus cepat mengikuti perkembangannya. Dunia pendidikan juga harus bisa mengikuti arus perkembangan untuk memudahkan setiap aktifitas dalam kegiatan mengajar maupun pada administrasinya. Saat ini masih terdapat beberapa sekolah yang dalam kegiatannya masih bersifat manual. Contohnya, dalam proses penerimaan peserta didik baru.

Sekolah yang masih menerapkan sistem pendaftaran peserta didik baru secara manual akan memakan banyak waktu dan tenaga, baik dari sisi orang tua yang harus rela meninggalkan pekerjaannya atau calon peserta didik baru yang harus antri dari pagi hingga sore dan berdesak-desakan dengan orang tua/calon peserta didik baru lainnya hanya untuk mendaftarkan diri pada sekolah tersebut. Hal yang sama juga akan dirasakan dari sisi panitia yang harus melayani para orang tua/calon peserta didik baru. Berbeda halnya dengan sekolah yang menerapkan sistem pendaftaran peserta didik baru secara online yang hanya memakan waktu dan tenaga yang lebih sedikit. Sebab, para orang tua/calon peserta didik baru dapat melakukan proses pendaftaran di mana saja dan kapan saja sehingga 
orang tua tidak perlu lagi meninggalkan pekerjaan mereka atau calon peserta didik baru tidak perlu antri dan berdesak-desakan. Salah satu sekolah yang sangat memerlukan adanya sistem pendaftaran online adalah Sekolah Putri Darul Istiqamah (SPIDI) Maros yang memiliki peserta didik yang berasal dari berbagai daerah, ada yang berasal dari pulau Sulawesi dan juga ada yang berasal dari luar pulau Sulawesi.

SPIDI adalah sekolah islam khusus putri yang menerapkan sistem boarding school dan terletak di Kab. Maros, Provinsi Sulawesi Selatan. SPIDI memiliki sejarah yang cukup panjang. Sekolah ini baru berubah nama menjadi Sekolah Putri Darul Istiqamah pada tahun 2011 dengan membuka jenjang SMP-IT dan SMA-IT. Saat ini Sekolah Putri Darul Istiqamah memiliki akreditasi A dengan konsep Go Green Campus. Dengan harapan, sekolah ini dapat menghasilkan generasi-generasi penerus islami yang merupakan tumpuan agama dan bangsa yang cerdas dan sholehah.

Berdasarkan hasil wawancara peneliti dengan pihak sekolah yang dilakukan pada tanggal 08 April 2019, diperoleh penjelasan yang mengatakan bahwa sebelumnya pada tahun 2015 SPIDI telah membuat laman untuk pendaftaran online yang dikerjasamakan dengan pihak ketiga yang menempatkan data dan aplikasinya di Silver Hawk Tech sebagai host server. Sistem informasi yang telah ada tersebut tidak dapat dikelola secara maksimal oleh pihak sekolah, tidak stabil dan juga membutuhkan biaya sewa hosting. Di akhir tahun 2018, sistem informasi tersebut menjadi tidak dapat diakses sama sekali sebagai akibat dari pemutusan hubungan kerjasama dengan pihak ketiga pada tahun 2017. Hal ini terjadi karena sistem tersebut menjadi expired sebab rutinitas untuk memperpanjang sewa hosting sebelumnya dilakukan oleh pihak ketiga hingga akhirnya diserahkan ke pihak sekolah. Pihak sekolah yang tidak terbiasa dengan hal tersebut, membuat mereka lupa untuk melakukan proses pembayaran sewa hosting.

Melihat kondisi tersebut, peneliti dan pihak sekolah merasa bahwa perlu adanya pembangunan website yang baru dengan fungsi yang sama namun dengan memanfaatkan layanan web hosting dari Google. Google merupakan sebuah perusahaan Amerika Serikat yang terkenal melalui mesin pencarinya memberikan layanan Google Suite for Education yang aman dan gratis kepada lembaga pendidikan sebagai bentuk dukungan dan kepedulian terhadap pendidikan sehingga sekolah yang memanfaatkan layanan Google Suite for Education tidak perlu lagi mengkhawatirkan pembayaran web hosting.

Menurut Purnawan dalam Lamada (2017) menyatakan bahwa pendidikan bidang keteknikan hendaknya memberikan teoriteori yang cukup dan mampu memberikan contoh-contoh pemecahan proyek-proyek nyata dengan memanfaatkan teori-teori yang ada. Dengan demikian, pengembangan profesi bidang keteknikan secara alamiah disimulasikan pada masalah-masalah teknik dalam situasi nyata. Oleh karena itu, peneliti yang merupakan mahasiswa yang menempuh pendidikan bidang keteknikan dan berdasarkan latar belakang yang telah dipaparkan di atas maka peneliti mengambil judul "Pengembangan Sistem Informasi Pendaftaran Online Pada Sekolah Putri Darul Istiqamah (SPIDI) Maros".

\section{LANDASAN TEORI}

\section{Kajian Teori}

1) Sistem juga merupakan suatu jaringan kerja dari prosedurprosedur yang saling berhubungan, terkumpul bersama-sama untuk melakukan suatu kegiatan atau untuk tujuan tertentu (Yakub, 2013).

2) Informasi adalah data yang telah diolah menjadi suatu bentuk yang penting bagi penerima dan mempunyai nilai nyata atau yang dapat dirasakan dalam keputusan-keputusan yang sekarang atau keputusan-keputusan yang akan datang (Hutahean, 2015).
3) Sistem informasi merupakan gabungan dari empat bagian utama yaitu perangkat lunak (software), perangkat keras (hardware), infrastruktur, dan sumber daya manusia (SDM) yang terlatih (Harianto, 2019).

4) Web berisi beragam informasi bagi pengguna baik informasi yang bersifat tidak serius hingga serius maupun informasi gratis hingga berbayar (Irwansyah, 2014).

5) Google Suite for Education adalah rangkaian aplikasi Google gratis yang didesain khusus untuk sekolah (edu.google.com).

\section{Kerangka Pikir}

Sekolah Putri Darul Istiqamah yang merupakan sekolah Islam khusus putri yang terakreditasi A dengan konsep Go Green Campus dan sistem boarding school menjadi daya tarik tersendiri bagi para calon peserta didik dan para orang tua. Besarnya daya tarik sekolah ini dapat dilihat dari antusias peserta didik yang berasal dari berbagai daerah. Sistem informasi pendaftaran tentu menjadi hal yang sangat dibutuhkan untuk memudahkan proses pendaftaran ini. Sebelumnya, yakni pada tahun 2015, Sekolah Putri Darul Istiqamah telah memiliki sistem informasi pendaftaran online dengan penyimpanan data pada server Silver Hawk Tech. Hanya saja, sistem tersebut tidak dapat dikelola secara maksimal oleh pihak sekolah, tidak stabil dan juga membutuhkan biaya sewa hosting. Di akhir tahun 2018, sistem informasi tersebut menjadi tidak dapat diakses sama sekali sebagai akibat dari pemutusan hubungan kerjasama dengan pihak ketiga pada tahun 2017. Hal ini terjadi karena sistem tersebut menjadi expired sebab rutinitas untuk memperpanjang sewa hosting sebelumnya dilakukan oleh pihak ketiga hingga akhirnya diserahkan ke pihak sekolah. Pihak sekolah yang tidak terbiasa dengan hal tersebut, membuat mereka lupa untuk melakukan proses pembayaran sewa hosting. Oleh karena itu, membangun sistem informasi pendaftaran online yang baru merupakan solusi atas permasalah ini. Hasil yang diharapkan adalah sistem informasi yang dibangun mudah untuk dikelola dan stabil. Untuk lebih jelasnya kerangka pikir dapat dilihat pada Gambar 1.

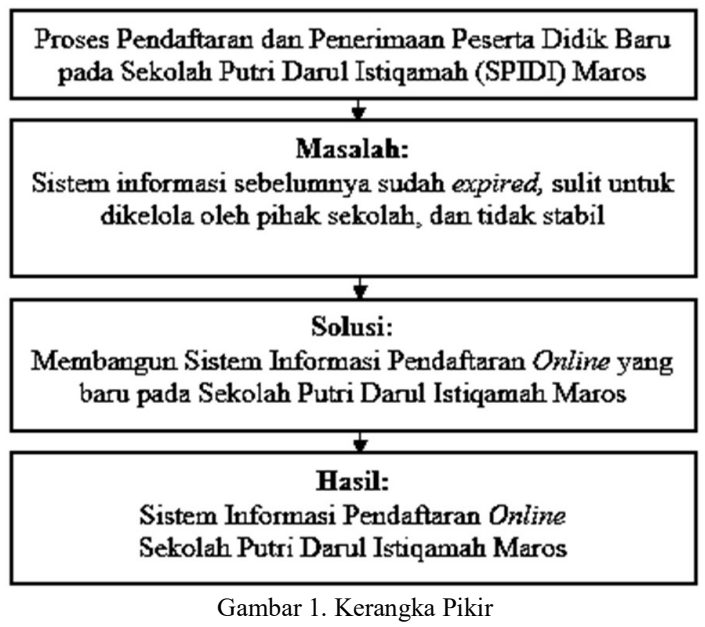

Jenis Penelitian

\section{METODE PENELITIAN}

Penelitian ini adalah penelitian dan pengembangan atau lebih dikenal dengan Research and Development (R\&D), dengan menggunakan incremental model. Penelitian dan Pengembangan adalah proses yang digunakan untuk mengembangkan dan memvalidasi produk pendidikan (Sutarti, 2017). 


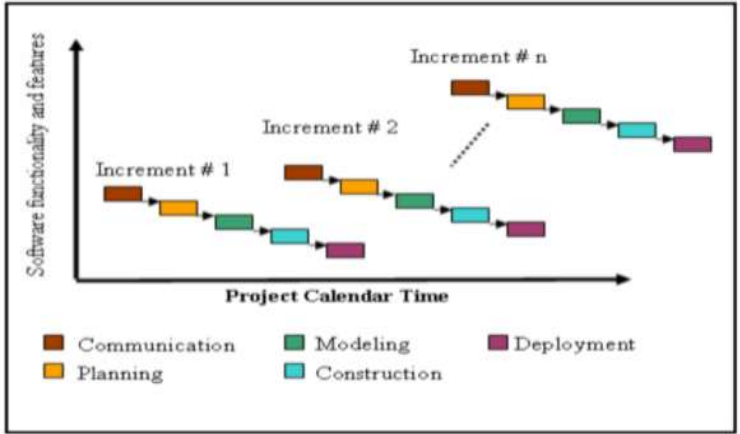

Gambar 2. Incremental Model

\section{HASIL DAN PEMBAHASAN}

\section{A. Hasil Penelitian}

\section{Increment 1}

1. Communication

- Pengembangan sistem PPDB online berbasis Google Suite for Education.

- Sistem yang akan dikembangkan dibagi menjadi dua bagian sesuai dengan tingkat kebutuhan yang mendesak.

- Calon Peserta Didik dapat mengisi formulir pendaftaran, konfirmasi pembayaran, dan pendaftaran ulang.

- Calon Peserta Didik menerima e-mail berupa surat sebagai tanda bukti bahwa data pendaftaran telah diterima.

- Panitia PPDB adalah petugas yang dapat melihat data yang telah diinput pada formulir.

- Panitia PPDB menerima e-mail surat tanda bukti pendaftaran untuk dijadikan sebagai arsip.

- Admin dapat mengelola GSuite yang telah dibuat.

- Super Admin dapat melakukan restore terhadap file yang terhapus.

2. Planning

Tabel 1. Kebutuhan Fungsional Increment 1

\begin{tabular}{|l|l|}
\hline \multicolumn{1}{|c|}{ Pengguna } & \multicolumn{1}{c|}{ Deskripsi Kebutuhan } \\
\hline Calon Peserta Didik & Mengisi fomulir pendaftaran \\
\cline { 2 - 2 } & $\begin{array}{l}\text { Mengisi formulir konfirmasi pembayaran biaya } \\
\text { pendaftaran }\end{array}$ \\
\cline { 2 - 2 } & Mengisi formulir konfirmasi pembayaran SPP awal \\
\cline { 2 - 2 } & Mengisi formulir pendaftaran ulang \\
\cline { 2 - 2 } & Menerima surat tanda bukti pendaftaran \\
\hline Panitia PPDB & Melihat laporan PPDB \\
\cline { 2 - 2 } & Menerima arsip surat tanda bukti pendaftaran \\
\hline Admin & Mengelola Gsuite \\
\hline Super Admin & Menerima informasi penghapusan \\
\cline { 2 - 2 } & Melakukan restore terhadap file yang terhapus \\
\hline
\end{tabular}

\section{Modelling}

Berdasarkan kebutuhan yang telah dianalisis maka tahap selanjutnya adalah melakukan pemodelan sistem. Tahap ini dilakukan dengan membuat rancangan sementara yang berfokus dengan penyajian kebutuhan pelanggan. Perancangan tersebut terdiri atas data flow diagram, entity relationship diagram, flowchart, use case, dan user interface.

\section{Construction}

Pada tahap construction increment 1 dilakukan pembangunan sistem dengan merealisasikan perancangan sistem menjadi serangkaian program dan unit program menggunakan layanan yang diberikan oleh Google yakni Google Suite for Education. Berikut adalah tampilan dari Sistem Informasi Pendaftaran Online Sekolah Putri Darul Istiqamah Maros.

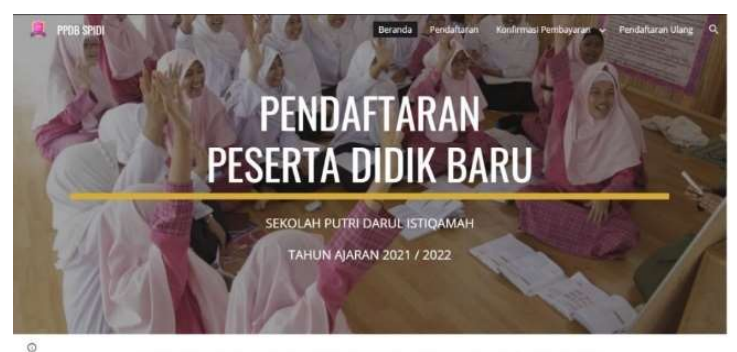

SELAMAT DATANG DI HALAMAN PPDB SEKOLAH PUTRI DARUL ISTIQAMAH
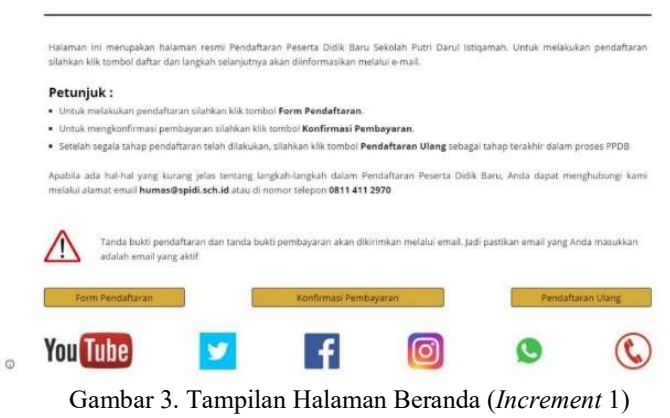

5. Deployment

Pada increment ini, dilakukan tahap hosting web yang dilakukan oleh Ketua ICT SPIDI setelah merasa sistem telah siap untuk dipublikasikan. Umpan balik dari user yang akan digunakan sebagai bahan untuk increment selanjutnya. Umpan balik yang diberikan oleh user yakni adanya pertambahan validasi terkait bukti pembayaran, slip pembayaran, tanda bukti pendaftaran ulang, dan tombol download untuk Panitia PPDB.

\section{Increment 2}

Tahapan pada increment 2 akan berfokus pada pengembangan sesuai dengan umpan balik yang diberikan oleh Ketua ICT SPIDI pada deployment increment 1 . Informasi dasar yang akan digunakan pada increment 2 juga terdapat pada increment 1 .

1. Communication

- Calon Peserta Didik menerima slip pembayaran biaya pendaftaran, slip pembayaran SPP awal, dan tanda bukti pendaftaran ulang.

- Staf Keuangan adalah yang bertugas untuk memvalidasi pembayaran.

- Panitia PPDB dapat mengunduh data pada sistem PPDB.

2. Planning

\begin{tabular}{|l|l|}
\multicolumn{1}{c|}{ Tabel 2. Kebutuhan Fungsional Increment 2} \\
\hline \multicolumn{1}{|c|}{ Pengguna } & \multicolumn{1}{c|}{ Deskripsi Kebutuhan } \\
\hline Calon Peserta Didik & Menerima slip pembayaran biaya pendaftaran \\
\cline { 2 - 3 } & Menerima slip pembayaran SPP awal \\
\cline { 2 - 2 } & Menerima surat tanda bukti pendaftaran ulang \\
\hline \multirow{2}{*}{ Staf Keuangan } & Menerima e-mail permohonan validasi \\
\cline { 2 - 2 } & Melakukan validasi pembayaran \\
\hline Panitia PPDB & Mengunduh data \\
\hline
\end{tabular}

3. Modelling

Berdasarkan kebutuhan yang telah dianalisis maka tahap selanjutnya adalah melakukan pemodelan sistem. Perancangan yang dilakukan pada increment 2 sama seperti perancangan yang dilakukan pada increment 1 . Perancangan tersebut adalah data flow diagram, entity relationship diagram, flowchart, use case, dan user interface.

4. Construction

Pada tahap construction increment 2 dilakukan pembangunan tambahan sistem dan pengujian sistem dengan menggunakan ISO 
25010. Berikut adalah tampilan yang mengalami perubahan akibat pertambahan.

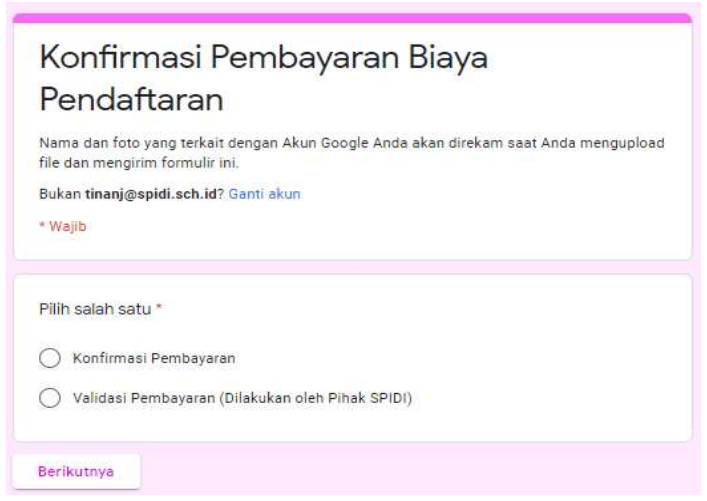

Gambar 4. Formulir Konfirmasi Pembayaran (Increment 2)

\section{Deployment}

Pada tahap deployment increment 2 dilakukan pembaharuan terhadap sistem informasi sebelumnya yang telah dihosting. Hasil pengerjaan pada increment 1 dan increment 2 telah digabungkan dan diintegrasi. Pada tahap ini harus dapat dipastikan bahwa sistem informasi yang telah dibuat dapat berjalan sebagaimana fungsinya dan telah memenuhi standar perangkat lunak ISO 25010. Dalam hal ini, akan dilakukan pengujian perangkat lunak dengan menggunakan standar iso 25010. Namun, sebelum dilakukan pengujian atau validasi produk, peneliti terlebih dahulu melakukan validasi instrumen agar poin-poin dalam instrumen layak untuk digunakan dalam kuesioner penelitian.

\section{Validasi Instrumen}

Validasi instrumen penelitian dilakukan sebelum pengembang melakukan pengujian pada aplikasi. Berdasarkan hasil validasi instrumen yang dilakukan oleh dua orang ahli instrumen dapat dilihat bahwa hasil pengujian oleh Ahli Instrumen 1 yang disajikan dalam bentuk persentase untuk instrumen functional suitability sebesar $90 \%$, untruk instrumen ahli sistem/media sebesar $98 \%$, untuk instrumen ahli materi/konten sebesar $96 \%$, dan untuk instrumen tanggapan responden sebesar $88 \%$. Hasil pengujian oleh Ahli Instrumen 2 untuk instrumen functional suitability sebesar $90 \%$, untuk ahli sistem/media sebesar $96 \%$, untuk instrumen ahli materi/konten sebesar 94\%, dan untuk instrumen tanggapan responden sebesar $90 \%$. Hasil rata-rata dari kedua ahli instrumen adalah 92,75\%. Dengan demikian dapat disimpulkan bahwa keseluruhan instrumen penelitian dapat dinyatakan sangat baik dan layak untuk digunakan sebagai alat pengumpulan data pada uji coba lapangan.

\section{Validasi Konten}

Tahap validasi konten sistem informasi pendaftaran online Sekolah Putri Darul Istiqamah Maros dilakukan oleh dua orang ahli materi/konten dari pihak SPIDI dengan pengisian angket berskala 1-5. Hasil penilaian kedua validator memberikan nilai yang sempurna dengan persentase $100 \%$ sehingga dapat dinyakan dalam kategori "Sangat Layak" untuk diterapkan di Sekolah Putri Darul Istiqamah (SPIDI) Maros.

\section{Validasi Media}

Tahap validasi media sistem informasi pendaftaran online Sekolah Putri Darul Istiqamah Maros dilakukan oleh dua orang ahli media dengan pengisian angket berskala 1-5. Hasil penilaian terdapat pada Lampiran 4 yang dapat dilihat bahwa total rata-rata skor yang diberikan oleh kedua validator adalah $86 \%$ yang dapat dinyakan dalam kategori "Sangat Baik" untuk diterapkan di Sekolah Putri Darul Istiqamah (SPIDI) Maros.

\section{Aspek Functional Suitability}

Pengujian aspek functional suitability adalah pengujian untuk melihat kemampuan perangkat lunak menjalankan fungsi sesuai kebutuhan pengguna dalam kondisi tertentu. Pengujian dan penilaian kualitas functional suitability dilakukan oleh validator untuk setiap pengujian pada aspek sistem dan program.

Tabel 3. Hasil Pengujian Functional suitability

\begin{tabular}{|c|c|c|c|c|}
\hline Validator & $\begin{array}{c}\text { Jumlah Fitur } \\
\text { yang Berhasil }\end{array}$ & $\begin{array}{c}\text { Jumlah Fitur yang } \\
\text { Tidak Berhasil }\end{array}$ & $\begin{array}{c}\text { Jumlah Fitur } \\
\text { yang Diuji }\end{array}$ & $x$ \\
\hline Ahli Sistem 1 & 18 & 0 & 18 & 1 \\
\hline Ahli Sistem 2 & 18 & 0 & 18 & 1 \\
\hline & & & Rata-Rata & 1 \\
\hline
\end{tabular}

Tabel 4. Hasil Persentase Perhitungan Functional suitability

\begin{tabular}{|c|c|c|c|c|c|}
\hline No. & Validator & Jumlah Skor & Skor Maksimal & $\%$ & Interpretasi \\
\hline 1 & Ahli Sistem 1 & 18 & 18 & 100 & Layak \\
\hline 2 & Ahli Sistem 2 & 18 & 18 & 100 & Layak \\
\hline \multicolumn{4}{|c|}{ Total Rata-Rata Skor } & 100 & Layak \\
\hline
\end{tabular}

Berdasarkan Tabel 3 dapat dilihat bahwa hasil pengujian functional suitability menghasilkan rata-rata penilaian sebesar 1 . Dengan interpretasi pengukuran dari ISO/IEC 25010 yaitu $0 \leq x \leq 1$ dengan perangkat lunak dapat dikatakan baik dalam aspek functionality apabila nilai x mendekati 1 maka sistem informasi yang dikembangkan layak untuk digunakan. Persentase dari pengujian functional suitability dapat dilihat pada Tabel 4 yang menunjukkan angka 100\% dengan interpretasi "Layak" sebagai hasil dari pengujian aspek functional suitability.

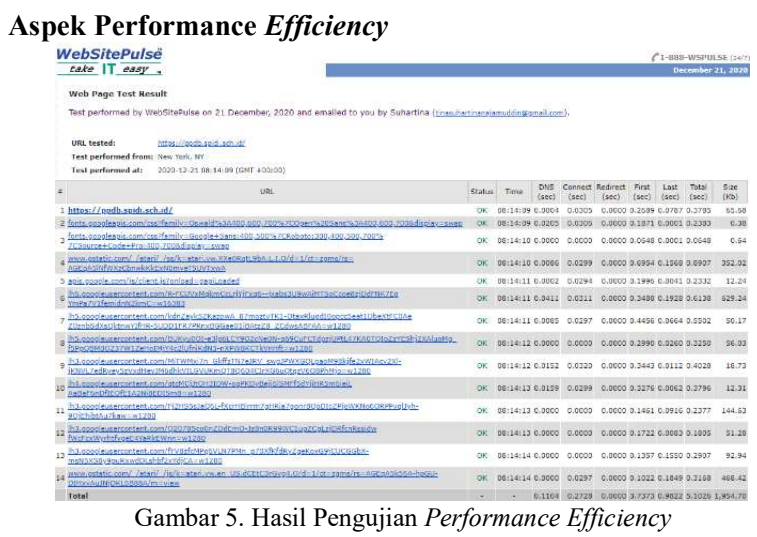

Berdasarkan hasil pengujian aspek performance efficiency pada Gambar 5 diperoleh status pengujian yaitu "OK", dengan total durasi akses yang dibutuhkan adalah sebanyak 5 second. Web dikatakan baik apabila waktu load setidaknya kurang dari 10 menit (Nielsen, 2010). Sehingga dapat disimpulkan bahwa sistem informasi yang dikembangkan telah memenuhi aspek performance efficiency.

\section{Aspek Compatibility}

Pengujian compatibility dilakukan dengan menggunakan compatibility testing tools yaitu IE Netrenderer yang berfungsi untuk memerika website yang dikembangkan mampu berjalan pada aplikasi Internet Explorer dengan versi yang berbeda. Berdasarkan hasil pengujian compatibility menggunakan software Internet Explorer versi 9, 10 dan 11 dapat dilihat bahwa sistem dapat diakses dengan baik.

\section{Aspek Reliability}

Pengujian reliability pada sistem ini menggunakan metode stress testing dengan menggunakan software WAPT Pro 5.0. Stress testing adalah salah satu metode pengujian sistem (system testing) untuk melihat apakah perangkat lunak secara keseluruhan mampu menangani kebutuhan sumber daya yang tidak normal atau melihat 
ketahanan suatu perangkat lunak dengan mengujinya diluar batas penggunaan yang normal. Pada WAPT Pro 5.0, peneliti menggunakan ramp-up sebagai main test goal untuk melakukan stress testing dengan spesifikasi dari 0 sampai 20 pengguna dan 2 step setiap 10 detik dalam durasi waktu 10 menit. Hasil pengujian tersbut dapat dilihat pada Gambar 4.38.

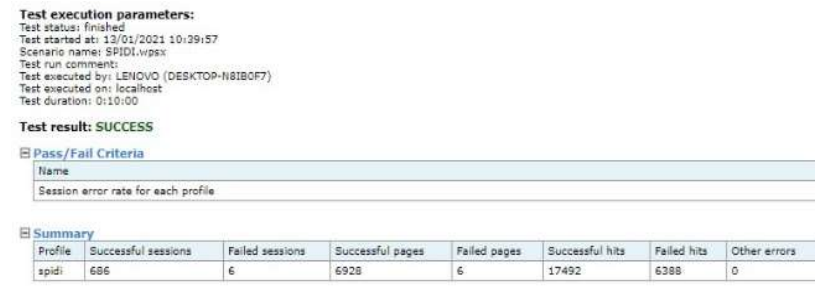

Gambar 6. Hasil Pengujian Reliability

Berdasarkan Gambar 6 dapat dilihat bahwa secara keseluruhan sistem informasi yang dikembangkan telah memenuhi aspek reliability dengan tercatat successful sessions 686, failed sessions 6, successful pages 6928, failed pages 6, successful hits 17492, failed hits 6388, dan other errors 0.

\section{Aspek Portability}

Tabel 5. Rekapitulasi Hasil Pengujian Portability

\begin{tabular}{|c|c|l|c|}
\hline No. & \multicolumn{1}{|c|}{ Senis Browser } & \multicolumn{1}{|c|}{ Sistem Operasi } & Hasil \\
\hline 1 & Google Chrome & $\begin{array}{l}\text { Windows 10, Android 8.1.0, Android 9, Android } \\
\text { 5.1.1, Android 5.0.2 }\end{array}$ & 100 \\
\hline 2 & Mozilla Firefox & Windows 10 & 100 \\
\hline 3 & Microsoft Edge & Windows 10 & 100 \\
\hline 4 & Opera Browser & Windows 10, Android 8.1.0 & 100 \\
\hline 5 & UC Browser & Android 8.1.0 & 100 \\
\hline & & Rata-Rata & 100 \\
\hline
\end{tabular}

Berdasarkan hasil rekap pengujian menggunakan browser pada sistem operasi pada Tabel 5 maka dapat dilihat bahwa sistem ini dapat diakses dengan baik pada browser yang berbeda-beda dan tidak terdapat error pada sistem tersebut.

\section{Aspek Usability}

Tabel 6. Hasil Pengujian Usabiilty

\begin{tabular}{|c|c|c|c|}
\hline Pertanyaan & Jumlah Total Jawaban & Rata-Rata & Kategori \\
\hline 1 & 145 & 4,53 & Sangat Baik \\
\hline 2 & 143 & 4,47 & Sangat Baik \\
\hline 3 & 144 & 4,50 & Sangat Baik \\
\hline 4 & 143 & 4,47 & Sangat Baik \\
\hline 5 & 136 & 4,25 & Sangat Baik \\
\hline 6 & 142 & 4,44 & Sangat Baik \\
\hline 7 & 143 & 4,47 & Sangat Baik \\
\hline 8 & 142 & 4,44 & Sangat Baik \\
\hline 9 & 136 & 4,25 & Sangat Baik \\
\hline 10 & 143 & 4,47 & Sangat Baik \\
\hline 11 & 139 & 4,34 & Sangat Baik \\
\hline 12 & 142 & 4,44 & Sangat Baik \\
\hline 13 & 117 & 3,66 & Baik \\
\hline 14 & 135 & 4,22 & Sangat Baik \\
\hline 15 & 135 & 4,22 & Sangat Baik \\
\hline 16 & 141 & 4,41 & Sangat Baik \\
\hline 17 & 135 & 4,22 & Sangat Baik \\
\hline 18 & 134 & 4,19 & Baik \\
\hline 19 & 131 & 4,09 & Baik \\
\hline 20 & 137 & 4,28 & Sangat Baik \\
\hline 21 & 137 & 4,28 & Sangat Baik \\
\hline 22 & 134 & 4,19 & Baik \\
\hline 23 & 134 & 4,19 & Baik \\
\hline 24 & 137 & 4,28 & Sangat Baik \\
\hline 25 & 136 & 4,25 & Sangat Baik \\
\hline 26 & 134 & 4,19 & Baik \\
\hline 27 & 136 & 4,25 & Sangat Baik \\
\hline \multicolumn{2}{|r|}{ Rata-Rata } & 4,30 & Sangat Baik \\
\hline
\end{tabular}

Berdasarkan hasil dari rekap data pada Tabel 6 memperoleh hasil 4,30 yang masuk dalam kategori Sangat Baik. Untuk persentasenya dapat dihitung $(4,30: 5)$ x 100 yang menghasilkan $86 \%$.

Adapun hasil analisis dengan menggunakan SPSS maka diperoleh data hasil pengujian usability yang dapat dilihat pada Tabel 4.7.

Tabel 7 Data Hasil Pengujian Usability Menggunakan SPSS

\begin{tabular}{llr}
\hline$N$ & Valid & 32 \\
& Missing & 0 \\
Mean & & 115.97 \\
Median & & 116 \\
Mode & & $104^{\mathrm{a}}$ \\
Std. Deviation & 12.99 \\
Variance & 168.68 \\
Range & & 55 \\
Minimum & & 80 \\
Maximum & & 135 \\
Sum & & 3711 \\
Percentiles & 25 & 106.25 \\
& 50 & 116 \\
& 75 & 127.5 \\
\hline
\end{tabular}

Berdasarkan Tabel 7 dapat dilihat bahwa jumlah variabel data sebanyak 32, dengan Mean 115,97, Median 116, Mode 104, Standar Deviasi 12,99, data minimum 80, maksimum 135, dan Sum 3711 .

Distribusi frekuensi dari hasil pengujian usability merupakan distribusi frekuensi numerik. Dalam pembuatan tabel distribusi numerik perlu menentukan interval kelasnya atau kelompok datanya dengan menghitung jumlah kelas menggunakan rumus Jumlah Kelas $=1+3,3 \log$ n. Setelah mengetahui jumlah kelas maka perlu untuk menghitung panjang kelas dengan menggunakan rumus Panjang Kelas $=$ Range/(Jumlah Kelas) . Hasil dari perhitungan tersebut maka ditetapkan interval kelas beserta frekuensinya seperti yang terdapat pada Tabel 8 . Tabel 8. Distribusi Frekuensi

\begin{tabular}{|c|c|}
\hline Interval Kelas & Frekuensi \\
\hline $80-89$ & 1 \\
\hline $90-99$ & 1 \\
\hline $100-109$ & 10 \\
\hline $110-119$ & 6 \\
\hline $120-129$ & 9 \\
\hline $130-139$ & 5 \\
\hline
\end{tabular}

Dari penilaian ini juga dihasilkan histogram yang dapat dilihat pada Gambar 4.37.

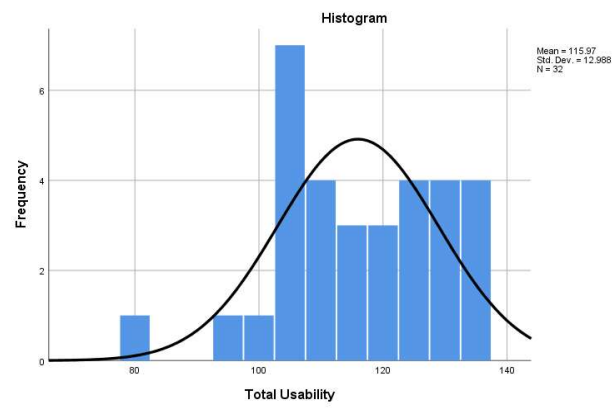

Gambar 7. Histogram Usability

Berdasarkan Gambar 7, dapat dilihat bahwa kurva tersebut menceng secara positif. Hal ini dikarenakan mean berada di tengah, median sebelah kanan dan modus sebelah kiri lazimnya juga ditulis Modus $<$ Mean $<$ Median. 


\section{B. Pembahasan}

Sistem informasi pendaftaran online Sekolah Putri Darul Istiqamah Maros merupakan sistem informasi pengolahan data-data dari calon peserta didik yang melakukan pendaftaran ke Sekolah Putri Darul Istiqamah Maros yang dimaksudkan untuk memberikan kemudahan bagi para calon peserta didik dalam melakukan pendaftaran terutama kepada calon peserta didik yang berasal dari berbagai daerah di Indonesia. Begitu pun dengan Panitia PPDB yang akan dimudahkan dalam mengelola data calon peserta didik.

Sistem informasi pendaftaran online Sekolah Putri Darul Istiqamah Maros berbasis web dikembangkan dengan menggunakan Google Suite for Education yang merupakan layanan yang diberikan oleh Google secara gratis sebagai bentuk dukungan terhadap dunia pendidikan dengan mengkolaborasikan beberapa layanan dari Google yakni, Google Mail, Google Drive, Google Office, Google Site dan Google Form.

Sistem ini dikembangkan dengan menggunakan metode pengembangan research and developoment $(\mathrm{R} \& \mathrm{D})$ yang termasuk dalam kategori pengembangan perangkat lunak. Adapun model pengembangan yang digunakan adalah incremental model dengan pertimbangan bahwa dengan menggunakan incremental model produk yang sudah dapat berfungsi dapat langsung digunakan meski secara keseluruhan produk tersebut masih dalam proses pengembangan. Pada increment 1 dilakukan pembangunan core product yakni formulir pendaftaran, konfirmasi pembayaran biaya pendaftaran, konfirmasi pembayaran biaya SPP awal, dan pendaftaran ulang serta templat e-mail tanda bukti pendaftaran untuk Calon Peserta Didik, view data untuk Panitia PPDB, pengalihan pengelolaan sistem untuk Admin, dan informasi penghapusan serta restore untuk Super Admin. Berdasarkan hasil evaluasi sistem pada increment 1 maka dibutuhkan increment 2 dengan pertambahan slip pembayaran pada setiap konfirmasi pembayaran, validasi pembayaran yang akan dilakukan oleh Staf Keuangan, dan pengunduhan data untuk Panitia PPDB. Setelah sistem yang dikembangkan telah mencapai produk akhir maka dilakukan pengujian sistem. Pengujian sistem ini dilakukan dengan menggunakan standar kelayakan ISO 25010 dengan pengujian beberapa aspek yakni, aspek functional suitability, performance efficiency, compatibility, reliability, portability dan usability.

Pengujian aspek functional suitability yang diuji oleh validator ahli dengan mengisi kuesioner dengan hasil pengujiannya adalah $100 \%$ sehingga evaluasi hasil pengujian dinyatakan berhasil dan layak untuk diimplementasikan. Pengujian aspek performance efficiency dilakukan dengan menggunakan test tools dari websitepulse dengan test performed from New York menghasilkan status pengujian pada sistem informasi pendaftaran online Sekolah Putri Darul Istiqamah adalah OK dengan total durasi akses yang dibutuhkan 5 second.

Pengujian aspek compatibility dilakukan dengan menggunakan compatibility testing tools yaitu IE Netrenderer yang berfungsi untuk mengetahui apakah website yang dikembangkan mampu berjalan pada aplikasi Internet Explorer dengan versi yang berbeda ataukah tidak. Pengujian compatibility menggunakan software Internet Explorer versi 9, 10 dan 11 menghasilkan bahwa sistem dapat berjalan pada aplikasi Internet Explorer dengan versi yang berbeda.

Pengujian aspek reliability dilakukan dengan menggunakan software WAPT Pro 5.0 dengan ramp-up sebagai main test goal untuk melakukan stress testing dengan spesifikasi dari 0 sampai 20 pengguna dan 2 step setiap 10 detik dalam durasi waktu 10 menit. Dari pengujian tersebut tercatat successful sessions 686, failed sessions 6, successful pages 6928, failed pages 6, successful hits 17492, failed hits 6388, dan other errors 0. Sehingga hasil pengujian reliability pada sistem adalah berhasil atau dengan kata lain sistem yang dikembangkan telah memenuhi aspek reliability.

Pengujian aspek portability dilakukan dengan menjalankan sistem informasi pendaftaran online Sekolah Putri Darul Istiqamah (SPIDI) Maros pada beberapa web browser berbasis desktop dan mobile. Adapun pengujian yang berbasis desktop yakni menggunakan Google Chrome, Mozilla Firefox, Microsoft Edge, dan Opera Browser pada sistem operasi Windows 10; serta pengujian versi mobile menggunakan Google Chrome, Opera Browser, dan UC Browser pada Android 8.1.0; Google Chrome pada Android 9, Android 5.1.1, dan Android 5.0.2. Hasil dari pengoperasian sistem informasi menunjukkan bahwa sistem berjalan dengan baik.

Pengujian aspek usability dilakukan dengan menggunakan tanggapan responden sebagai user dari sistem ini. Responden merupakan calon user sistem informasi pendaftaran online Sekolah Putri Darul Istiqamah. Pengenalan sistem kepada responden dilakukan secara online yakni dengan membuat suatu video tutorial penggunaan sistem tersebut. Adapun responden ingin mencoba menggunakan sistem secara langsung maka responden dapat membuka website melalui link yang dibagikan. Kemudian setelah responden merasa telah cukup mengenal sistem maka responden mengisi kuesioner secara online yakni dengan menggunakan Google form yang unit pertanyaannya telah divalidasi oleh validator instrumen. Hasil dari pengujian aspek usability diperoleh persentase sebesar $78 \%$ atau 21 pernyataan dengan kategori hasil penilaian sangat baik dan sebesar $22 \%$ atau 6 pernyataan dengan kategori hasil penilaian baik. Adapun rata-rata skor responden menghasilkan persentase sebesar $86 \%$ dengan kategori sangat baik. Sehingga hasil pengujian secara keseluruhan dapat disimpulkan bahwa sistem mendapatkan tanggapan yang sangat baik dari responden.

Berdasarkan hasil dari penelitian Pengembangan Sistem Informasi Pendaftaran Online Sekolah Putri Darul Istiqamah (SPIDI) Maros setelah divalidasi dan dilakukan pengujian menggunakan standar kelayakan ISO 25010 ditinjau dari aspek functional suitability, performance efficiency, compatibility, reliability, portability dan usability, dapat disimpulkan bahwa sistem informasi dapat digunakan oleh pengguna.

\section{KESIMPULAN}

bahwa:

Berdasarkan hasil penelitian maka dapat disimpulkan

1. Hasil Pengembangan Sistem Informasi Pendaftaran Online Sekolah Putri Darul Istiqamah (SPIDI) Maros dikembangkan dengan menggunakan Google Suite for Education dan menggunakan incremental model sebagai model pengembangan dengan langkah-langkah pengembangannya yakni communication, planning, modeling, construction, dan deployment telah mengasilkan sistem informasi yang mendukung proses pendaftaran peserta didik baru.

2. Increment 1 menghasilkan core product yang memuat formulir pendaftaran serta tanda bukti pendaftaran, konfirmasi pembayaran biaya pendaftaran, konfirmasi pembayaran SPP awal, pendaftaran ulang; view data untuk panitia PPDB; pengelolaan sistem untuk Admin; dan informasi penghapusan serta fitur restore untuk Super Admin. Sedangkan increment 2 menghasilkan pertambahan berupa proses validasi pembayaran, slip pembayaran biaya pendaftaran, slip pembayaran SPP awal, tanda bukti pendaftaran ulang, dan fungsi unduh data untuk panitia PPDB.

3. Berdasarkan hasil pengujian pengembangan sistem informasi pendaftaran online Sekolah Putri Darul Istiqamah (SPIDI) Maros berdasarkan standar kelayakan ISO 25010 pada aspek functional suitability, performance efficiency, compatibility, reliability, portability dan usability maka diperoleh hasil 
sebagai berikut: 1) Aspek functional suitability memperoleh nilai 1 dengan kategori diterima; 2) Aspek performance efficiency memperoleh status ok dengan total durasi akses yang dibutuhkan adalah 5 detik; 3) Aspek compatibility menghasilkan bahwa sistem dapat berjalan pada aplikasi Internet Explorer versi 9, 10 dan 11; 4) Aspek reliability menghasilkan successful sessions 686, failed sessions 6, successful pages 6928, failed pages 6, successful hits 17492, failed hits 6388, dan other errors 0 yang secara keseluruhan pengujian reliability berhasil atau sukses; 5) Aspek Portability menghasilkan bahwa sistem dapat berjalan pada berbagai web browser dengan sistem operasi yang berbeda-beda pada perangkat yang berbeda pula; dan 6) Aspek Usability menghasilkan persentase $86 \%$ dengan kategori sangat baik.

\section{DAFTAR PUSTAKA}

[1] Alfianika, Ninit. 2018. Buku Ajar Metode Penelitian Pengajaran Bahasa Indonesia. Yogyakarta: Deepublish.

[2] Arianti, Dwi. _. Model Incremental (Model Pengembangan $R P L)$. https://www.scribd.com, diakses 25 Juli 2019.

[3] Astuti, Rahmaniyah Dwi dan Iftadi, Irwan. 2016. Analisis dan Perancangan Sistem Kerja. Yogyakarta: Deepublish.

[4] Azminuddin. 2019. Fundamental Pemrograman. Yogyakarta: Deepublish.

[5] BPS. 2018. Indeks Pembangunan Teknologi Informasi dan Komunikasi (IP-TIK) Indonesia Tahun 2017 Sebesar 4,99 pada Skala 0-10. https://www.bps.go.id, diakses 14 Mei 2019.

[6] Fatta, Hanif Al. 2007. Analisis dan Perancangan Sistem Informasi untuk Keunggulan Bersaing Perusahaan dan Organisasi Modern. Yogyakarta: Andi.

[7] G Suite. _. Produk Google Suite for Education. https://edu.Google.com, diakses 15 Mei 2019.

[8] Gaol, Chr Jimmy L. _. Sistem Informasi Manajemen Pemahaman dan Aplikasi. Jakarta: Grasindo

[9] Google for Education. _.Pusat Keamanan \& Privasi. https://edu.Google.com, diakses 24 Juni 2021

[10] Harianto, Kusno dkk. 2019. Sistem Monitoring Lulusan Perguruan Tinggi Dalam Memasuki Dunia Kerja Menggunakan Tracer Study. Surabaya: MSC.

[11] Hartati, Sri. 2012. Research And Development (R\&D) Sebagai Salah Satu Model Penelitian Dalam Bidang Pendidikan. Vol. 37 No. 1.

[12] Harun, Muhammad. 2018. Evaluasi Kualitas Perangkat Lunak Dengan ISO/IEC 25010:2011 (Study Kasus : Aplikasi First AID Pada Platform Android). Jurnal Akrab Juara, (on line), vo. 3, no. 3, (https://akrabjuara.com, diakses 24 Juli 2019)

[13] Hutahaean, Japerson. 2015. Konsep Sistem Informasi. Yogyakarta: Deepublish

[14] Irwansyah, Edy. 2014. Pengantar Teknologi Informasi. Yogyakarta: Deepublish.

[15] KBBI. _. Arti kata Web. https://kbbi.kemdikbud.go.id, diakses 15 Mei 2019.

[16] Kominfo. 2014. Kemkominfo: Pengguna Internet di Indonesia Capai 82 Juta. https://kominfo.go.id, diakses 15 Mei 2019

[17] Kompas. 2013. Asal Usul Nama Google. http://tekno.kompas.com, diakses 15 Mei 2019.

[18] Kristanto, Vigih Hery. 2018. Metodologi Penelitian Pedoman Penulisan Karya Tulis Ilmiah (KTI). Yogyakarta: Deepublish.

[19] Kusnendi. . Modul 1 Konsep Dasar Sistem Informasi. https://repository.ut.ac.id, diakses pada 19 Juni 2019.

[20] Lamada, Mustari S. dan Karim, Sugeng A. 2017. Analisis Kebutuhan PBL Pada Mata Kuliah Pemrograman Web
Program Studi Pendidikan Teknik Informatika dan Komputer Fakultas Teknik Universitas Negeri Makassar, (Online), jilid 2, nomor 1, (www.unm.ac.id, diakses 16 Juli 2019).

[21] Lewis, James R. 1993. IBM Computer Usability Satisfaction Questionnaires: Psychometric Evaluation and Instructions for Use. Diakses dari: http:// drjim.0catch.com/usabqtr.pdf. Pada tanggal 20 Juli 2019

[22] Marimin dkk. _. Sistem Informasi Manajemen Sumber Daya Manusia. Jakarta: Grasindo

[23] Mulyani, Sri. 2016. Analisis dan Perancangan Sistem Informasi Manajemen Keuangan Daerah: Notasi Pemodelan Unified Modeling Language (UML). Bandung: Abdi Sistematika.

[24] Muslihudin, Muhamad dan Oktafianto. 2016. Analisis dan Perancangan Sistem Informasi Menggunakan Model Terstruktural dan UML. Yogyakarta: Andi.

[25] Nielsen, J. 2010. Website Response Times. Diakses dari https://www.nngroup.com/articles. Pada 17 Desember 2020.

[26] Nurdin. 2007. Pengantar Komunikasi Massa. Jakarta: PT Rajagrafindo Persada.

[27] Nuryanto, Hery. 2012. Sejarah Perkembangan Teknologi Informasi dan Komunikasi. Jakarta Timur: PT Balai Pustaka.

[28] PPDB. _. Turut Membangun Pendidikan Untuk Negeri. https://siap-ppdb.com, diakses pada 2 Juli 2019.

[29] Prabowo, Mei. 2020. Metodologi Pengembangan Sistem Informasi. Salatiga: LP2M IAIN Salatiga

[30] Prasetyo, Eddy. 2011. Rekayasa Perangkat Lunak. Bandung: Politeknik Telkom.

[31] Prehanto, Dedy Rahman. 2020. Buku Ajar Konsep Sistem Informasi. Surabaya: Scopindo

[32] Ramdhan, Nur Ariesanto. 2019. Sistem Informasi Penerimaan Peserta Didik Baru (PPDB) Berbasis WEB Di $S M P$ Negeri 1 Wanasari Brebes. Information Technology Journal (INTECH) of UMUS. Vol. 1 No.1.

[33] Rerung, Rintho Rante. 2018. Pemrograman Web Dasar. Yogyakarta: Deepublish.

[34] Rianto, Indra. 2021. Rekayasa Perangkat Lunak. Klaten: Lakeisha

[35] Rusmawan, Uus. 2019. Teknik Penulisan Tugas Akhir dan Skripsi Pemrograman. Jakarta : Gramedia.

[36] Setyosari, Punaji. 2016. Metode Penelitian Pendidikan dan Pengembangan. Jakarta: Prenadamedia Group.

[37] SPIDI. _. Profile Sekolah Putri Darul Istiqamah. https://spidi.sch.id, diakses 14 Mei 2019

[38] Suharsimi, Arikunto. 2006. Prosedur Penelitian: Suatu Pendekatan Praktik. Jakarta: PT Rineka Cipta.

[39] Suprapto, Untung. 2021. Pemodelan Perangkat Lunak. Jakarta: Grasindo

[40] Sutabri, Tata. 2013. Konsep Sistem Informasi. Yogyakarta: Andi Offset.

[41] Sutarti, Tatik dan Irawan, Edi. 2017. Kiat Sukses Meraih Hibah Penelitian Pengembangan. Yogyakarta: Deepublish.

[42] Syafril. 2019. Statistik Pendidikan. Jakarta: Kencana Prenada Media Group.

[43] Tyoso, Jaluanto Sunu Punjul. 2016. Sistem Informasi Manajemen. Yogyakarta: Deepublish.

[44] Wahid, Fathul. 2004. Metodologi Penelitian Sistem Informasi: Sebuah Gambaran Umum. Media Informatika. Vol. 2 No. 1.

[45] Wijaya, Andi dan Aliyanto, Arif. 2016. Analisis Kegunaan dan Kemudahan terhadap Penggunaan Google Apps for Education. Makalah disajikan dalam Seminar Nasional Inovasi dan Aplikasi Teknologi di Industri (SENIATI) yang 
Jurnal MediaTIK : Jurnal Media Pendidikan Teknik Informatika dan Komputer

diselenggarakan oleh Institut Teknologi Nasional Malang. Malang. 2016.

[46] Yakub. 2013. Pengantar Sistem Informasi. Yogyakarta: Graha Ilmu.

[47] Yaumi, Muhammad. 2018. Media \& Teknologi Pembelajaran. Jakarta: Prenadamedia.

[48] Yusa, I Made Marthana, 2016. Sinergi Sains, Teknologi dan Seni Dalam Proses Berkarya Kreatif di Dunia Teknologi Informasi. Denpasar: STIMIK STIKOM Indonesia.

[49] Zaef, Rizqi Muharom, dkk. 2018. Sistem Informasi Penerimaan Peserta Didik Baru Berbasis Android Menggunakan Metode Agile. Banyuwangi: Sekolah Tinggi Ilmu Komputer Banyuwangi.

[50] Zain, Achmad Syafi, dkk. 2018. Pengembangan Sistem Informasi Penerimaan Siswa Baru Berbasis Web di SMA 1 Annuqayah Sumenep. Jurnal Ilmiah Edutic. Vol. 4 No. 2. 